\title{
ORGANOMETALLIC CHEMISTRY OF BIMETALLIC COMPOUNDS
}

\author{
Department of Energy \\ Division of Basic Energy Sciences
}

Grant Number DE-FG-02-85ER13406

Research Plans for Coming Year

July 1992

Charles P. Casey, Principal Investigator

University of Wisconsin - Madison

Madison, Wisconsin 53706

\section{DISCLAIMER}

This report was prepared as an account of work sponsored by an agency of the United States Government. Neither the United States Government nor any agency thereof, nor any of their employees, makes any warranty, express or implied, or assumes any legal liability or responsibility for the accuracy, completeness, or usefulness of any information, apparatus, product, or process disclosed, or represents that its use would not infringe privately owned rights. Reference herein to any specific commercial product, process, or service by trade name, trademark, manufacturer, or otherwise does not necessarily constitute or imply its endorsement, recommendation, or favoring by the United States Government or any agency thereof. The views

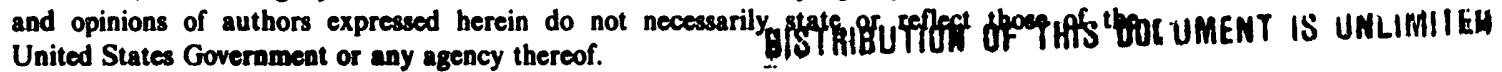

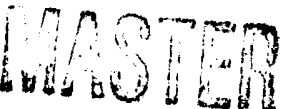

40,00 . 
Reactions of Heterobimetallic Dihydrides. We will continue investigations of the mechanism of the hydrogenation of alkynes by the heterobimetallic compound $\mathrm{C}_{5} \mathrm{H}_{5}(\mathrm{CO})_{2} \mathrm{Re}(\mu-\mathrm{H}) \mathrm{Pt}(\mathrm{H})\left(\mathrm{PPh}_{3}\right)_{2}$ which produces rhenium alkene complexes. We will attempt to synthesize a proposed intermediate in this reaction from the reaction of hydride with a rheniumplatinum $\mu$-vinyl complex. We will attempt to access the same intermediate from the reaction of $\mathrm{H}_{2}$ with the unusual rhenium platinum alkyne complex shown below.
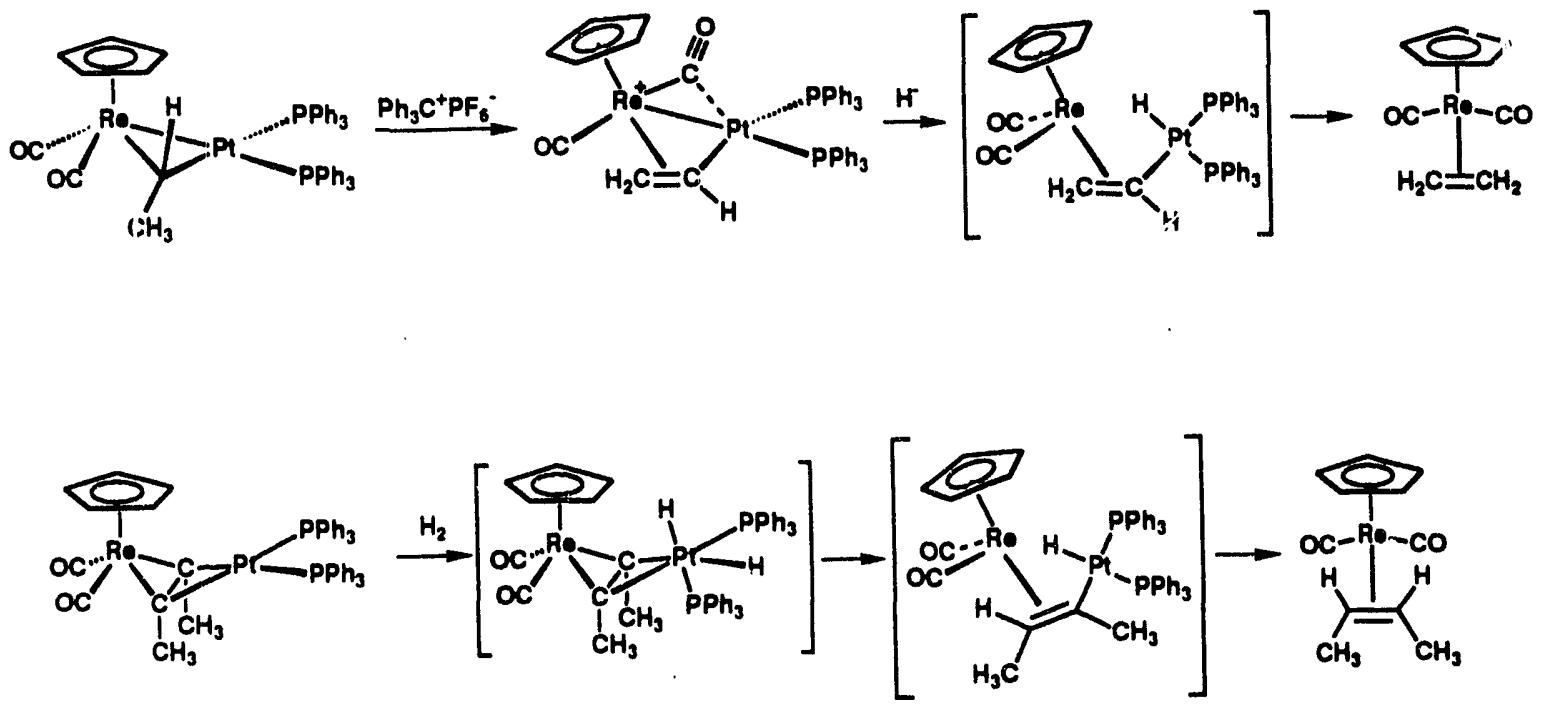

Future work will center on the search for a heterobimetallic dihydride that will reduce alkynes to metal alkene complexes and also allow release of the alkene from the metal complex. To develop a useful catalyst system, we will also have to solve the problem of regeneration of the heterobimetallic dihydride from reaction with $\mathrm{H}_{2}$. 
Metal-Metal Double Bonds. We synthesized the unusual compound $\mathrm{C}_{5} \mathrm{Me}_{5}(\mathrm{CO})_{2} \mathrm{Re}=\mathrm{Re}(\mathrm{CO})_{2} \mathrm{C}_{5} \mathrm{Me}_{5}$ in which two $16 \mathrm{e} \mathrm{d}^{6}$ fragments are joined by a metal-metal bond supported only by semibridging carbonyl groups. We will continue to study the basic chemistry of this fascinating compound. We have begun studies of its reaction with zirconium alkyls and zirconium hydrides. We are also interested in reactions with ligands which are variable $2 e$ or $4 e$ donors such as alkynes, alkoxides, and dienes.
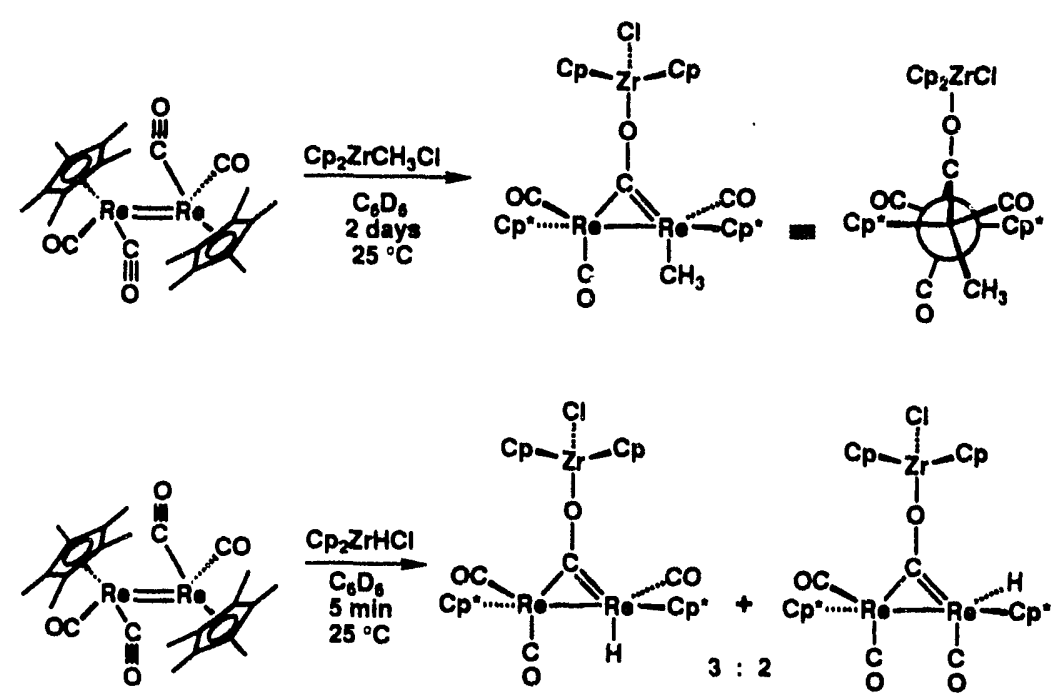
Reactions of $\left[\left(\mathrm{C}_{5} \mathrm{M} \mathrm{e}_{5}\right) \mathrm{CO}_{3}\right]_{3}\left(\mu_{2}-\mathrm{H}\right)_{3}\left(\mu_{3}-\mathrm{H}\right)$ and $\left(\mathrm{C}_{5} \mathrm{Me}_{5}\right) \mathrm{Co}(\mu-\mathrm{H})_{3} \mathrm{Co}\left(\mathrm{C}_{5} \mathrm{Me}_{5}\right)$. We will continue our collaboration with Professor Klaus Theopold of the University of Delaware on studies of compounds discovered in a reinvestigation of a spurious report of $\left(\mathrm{C}_{5} \mathrm{Me}_{5}\right) \mathrm{Co}=\mathrm{Co}\left(\mathrm{C}_{5} \mathrm{Me}_{5}\right)$. Initially we have concentrated on the reactions of these compounds with $\mathrm{CO}$ and have discovered an intermediate in the reaction of $\mathrm{CO}$ with $\left[\left(\mathrm{C}_{5} \mathrm{Me}_{5}\right) \mathrm{Co}_{3}\left(\mu_{2}-\mathrm{H}\right)_{3}\left(\mu_{3}-\mathrm{H}\right)\right.$.

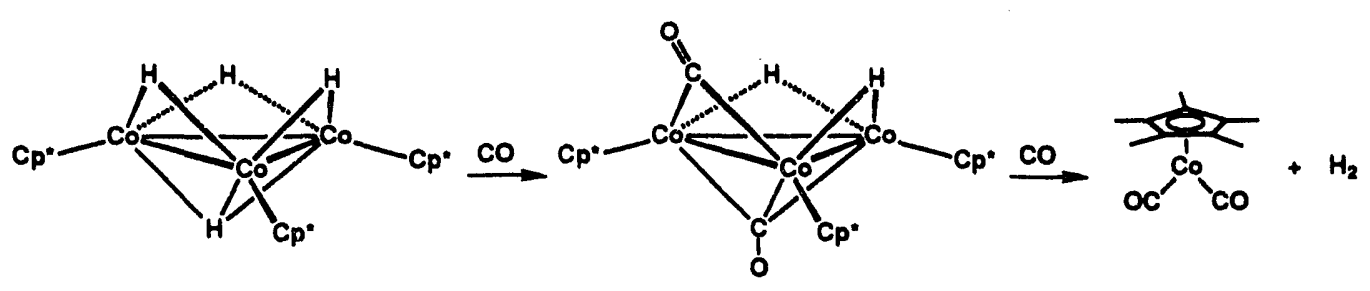


Wide Bite Angle Phosphines in Hydroformylation. We will study the deuterioformylation of alkenes using wide bite angle phosphines to determine whether the observed high selectivity for straight chain aldehydes is due to kinetic formation of a primary alkyl or to equilibration of rhenium primary and secondary alkyls prior to hydroformylation.

Test for Reversibllity of Rhodlum Alkyl Formation Deuterioformylation of 1- Hexene
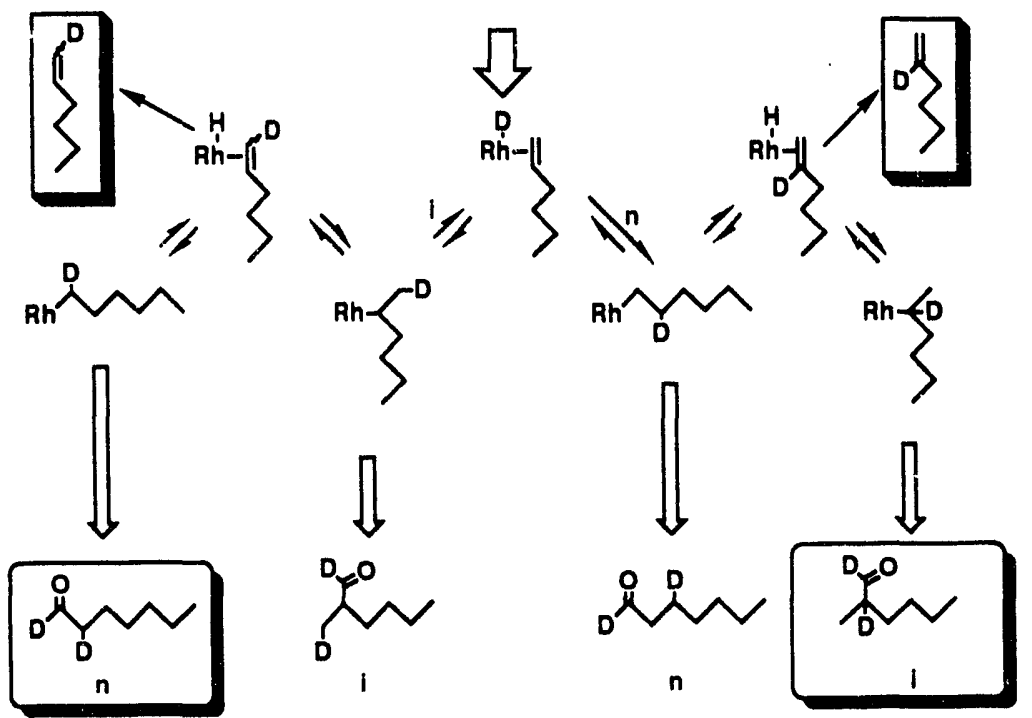

We will also design and synthesize ligands with various wide bite angles and with differing ligand flexibility to assess the importance of ligand flexibility in controlling the regiochemistry of hydroformylation. 

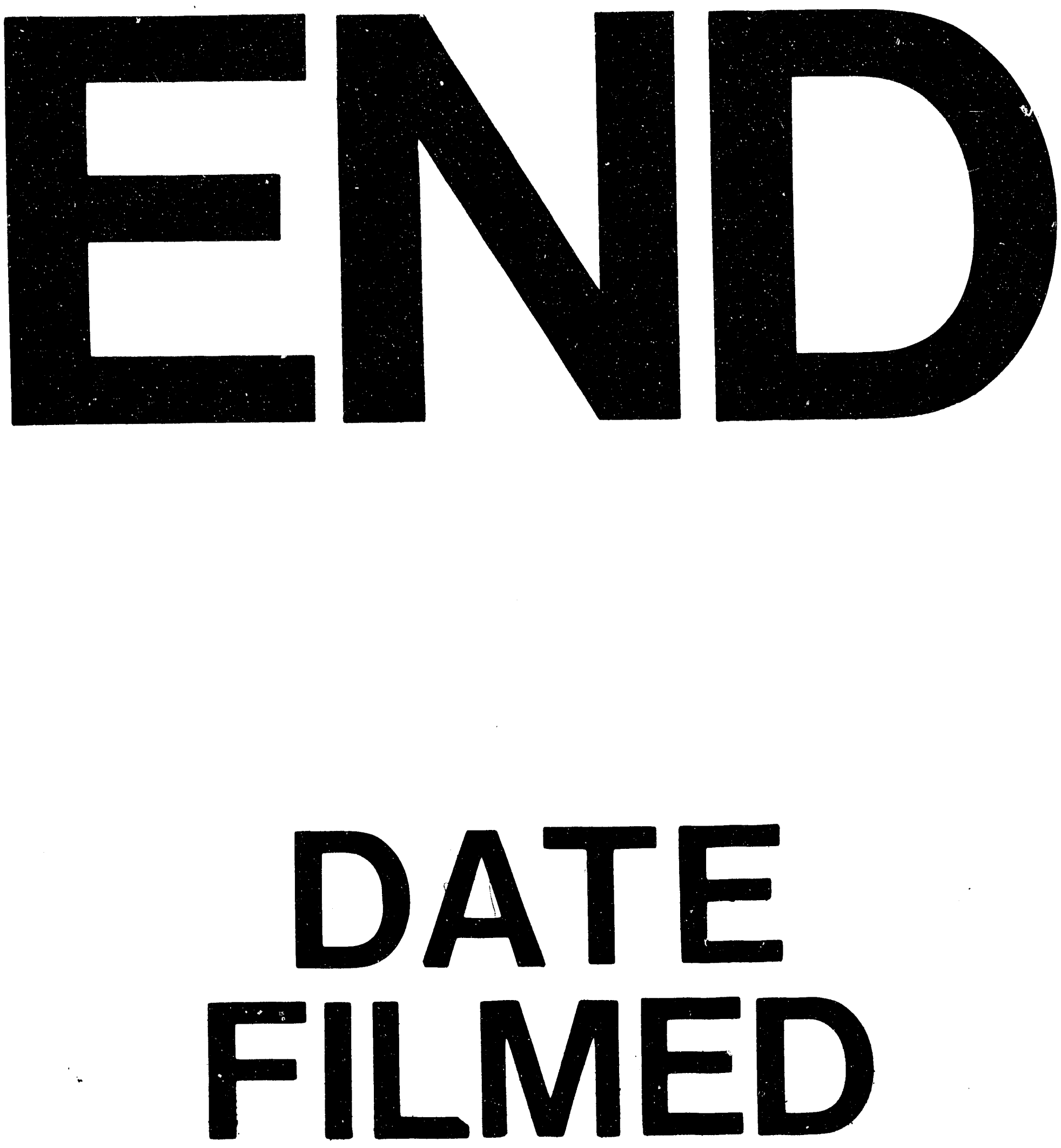

I

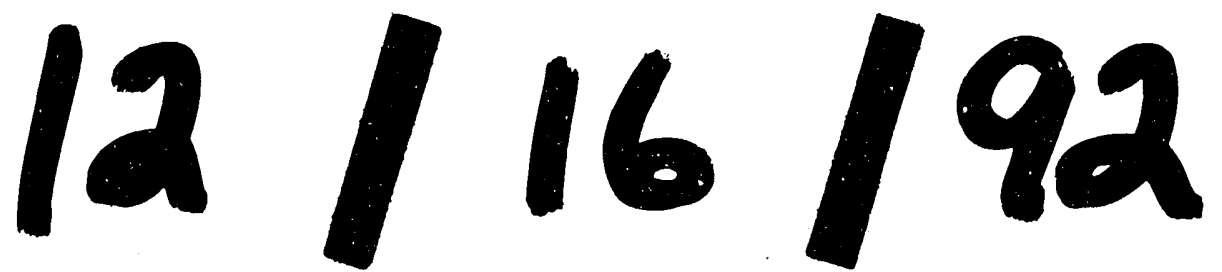


